\title{
Determinants of Company Capital Structure
}

\section{(Empirical Study on Lq-45 Index Companies on the Indonesia Stock Exchange)}

\author{
I Ketut Mangku, Fikri Budi Aulia, Yayuk Apriani \\ Faculty of Economics and Business \\ Janabadra University, UJB \\ Yogyakarta, Indonesia \\ ketut@janabadra.ac.id
}

\begin{abstract}
This study aims to prove empirically that sales growth, profitability, asset structure, business risk, financial risk, tax, Firm growth and firm size are determinants of the capital structure decisions of companies incorporated in the LQ45 index on the Indonesia Stock Exchange. The sample was taken using purposive random sampling, and the collected panel data were analyzed using panel data regression. The results showed that the independent variables that had a significant effect on the capital structure proxied by the debt to asset ratio (DAR) were: sales growth, profitability, asset structure, and firm size
\end{abstract}

Keywords: sales growth, profitability, asset structure, business risk, financial risk, tax magnitude, firm growth, Firm size

\section{INTRODUCTION}

Companies everywhere are generally not net savers (net dissavers). This term is an economist's way of saying that companies need more capital to invest, than can be provided in the form of retained earnings. Companies must cover this financial deficit by borrowing or issuing new equity securities. Large companies face four main financing decisions on a sustainable basis, namely: (1) how much capital must be raised each year? (2) How much of this need to be collected from external sources other than through retained earnings? (3) How much external financing should be raised through bank loans, and other financial intermediaries, and how much capital should be raised by selling securities directly to investors? and (4) How much is the need for external funding that should be proportioned as common stock, preferred stock, or long-term debt. The answer to this question depends primarily on the company's capital budgeting process. The company must raise sufficient capital to finance all its investment projects that generate a positive NPV and cover all its working capital requirements. The correct funding decision starts with question number 2, namely the choice of internal versus external funding sources [24]. This funding option from debt and equity is called the capital structure decision [3].

The company's capital structure is specifically defined as the percentage of each type of capital supplied by investors, which if the total proportion is added together, it will be $100 \%$ [2]. Meanwhile, the optimal capital structure of a company is a combination of debt, preferred stock, and common equity that can maximize the intrinsic value of its shares. As we can see, the capital structure that maximizes the intrinsic value of the company's shares also minimizes

\author{
Arisudana Yoga Pramana \\ Statistics of Papua Province \\ Jln. Sam Ratulangi Street, Jayapura, Papua, Indonesia \\ arisudana.pramana@bps.go.id
}

the weighted average cost of capital (WACC). The different theories lead to different conclusions about the optimal capital structure, and no one is able to prove a theory is better than another. Therefore we cannot estimate the optimal capital structure with exactly [2]. Thus financial executives generally determine the optimal capital structure as a range for example $40 \%$ to $50 \%$ debt rather than as a fixed point, say $45 \%$ debt. So the concepts and theories about capital structure serve only as a guide, helping managers understand the factors to consider when they are setting a targeted capital structure for their firm. Companies generally consider the following factors in making decisions of capital structure. (1) sales stability, (2) asset structure, (3) operating leverage, (4) growth rate, (5) profitability, (6) taxes, (7) control, (8) management attitude, (9) attitudes of lenders and rating agencies, (10) market conditions, and (11) internal conditions of the company [2].

The assessment of the performance and fundamental condition of the company after the securities that are issued in order to raise capital are highly depend on investors perceptions of the company's shares in the capital market. This will be reflected in stock price movements as shown by the stock price index. Investors in investing the money are looking for returns and avoiding risk, so the action of buying at a low price and selling at a high price that takes place on the stock exchange will affect the liquidity of shares. Meanwhile, the good fundamental condition of listed companies is a strong consideration for passive investors because they are risking their investment in the long term. The right study is to take the object of companies that are included in the LQ45 index because companies whose shares are included in the LQ45 index are companies that have strong fundamental conditions, including their capital structure.

This research tries to reveal the determinants of capital structure as stated in the previous section [2], by conducting empirical studies on companies that are members of the LQ45 index, from 2009 to 2018 . The results of this study are expected to contribute positively to the development of science especially financial management, for companies to maintain and improve their fundamental conditions internally, and for investors to find places to invest that maximize their portfolio returns.

\section{Problem Formulation}

This study aims to answer the research question whether the factors: sales growth, profitability, asset structure, 
business risk, financial risk, taxes, firm growth, and firm size determine the capital structure decisions of companies that are included in the LQ45 index on the Indonesia Stock Exchange.

\section{LITERATURE REVIEW}

\section{A. Literature Review and Previous Research}

Corporate financeis concerned with the financial management of the organization efficiently and effectively in effort to achieve the goals of the organization [25]. Company financial managers face two big questions in finance, namely: First, what investment should the company make? Second, how to finance the investment? Investment decisions with respect to the use of funds; and financing decisions regarding to raise of the required funds [3].Financial management, also known as corporate finance, focuses on decisions related to how many and what types of assets the company needs, and how to raise the capital needed to buy these assets, and how to run the company so that it can maximize its value. These principles can be applied to both profit oriented and non-profit oriented organizations [2].

One of the main functions of financial management is to raise capital to fund investments in assets needed by the company to achieve its objectives, namely maximizing company value, or shareholder value [24]; [3]; and [2], Thus financing function will determine whether or not the company's decided investment plan can be carried out or not. The term capital refers to funds that investors supply through debt, preferred stock, common stock and retained earnings. Accounts payable and accruals are not included in the definition of capital because they are not supplied by investors. This debt comes from suppliers, employees and tax authorities, which is a result of normal business operations, not from investments made by investors [2].Capital structure is a combination (or proportion) of the company's permanent long-term financing, which is represented by debt, preferred stock, and common equity [24].

The modern theory of capital structure began in 1958 when Modigliani and Miller (MM) published the most influential article that has never been written by anyone before. The MM study are based on the assumption of perfect market conditions. There are not transaction cost, taxes, and bankruptcy cost, all investors have the same information as the company's management about the company's future investment opportunities, investors can borrow at the same interest rate as the company, earnings before interest and tax (EBIT) is not affected by debt financing. With a number of strict assumptions, MM argues that firm value is not influenced by its capital structure.

In 1963, following up on various criticisms of his first peper, MM renewed his theory by eliminating the assumption that there was no corporate tax. MM argues that if all the assumptions in the theory stated earlier are maintained, except for taxes, the different tax treatment between debt interest and dividends encourages companies to use $100 \%$ of debt on their capital structure to achieve the optimal capital structure.

MM theory in 1963, modified a few years later by Miller (not with Modigliani) to include a personal tax consideration (personal tax) on interest income, and taxes on dividends and capital gains on shares. The conclusion shown by Miller is that, (1) deduction of tax expense from debt interest, provides an advantage for the use of debt financing. (2) More favorable personal tax treatment of income from shareholders, which can reduce the required rate of return on shares and thereby encourage the use of equity. Although it is difficult to determine the net effect of these two factors, most observers believe that reduced interest has a stronger effect and therefore the tax system supports the use of debt in corporate financing.

The trade-off theory is a capital structure theory which states that companies make a trade-off between tax advantages from debt financing and problems caused by potential bankruptcy [2]. With the assumption that there is no bankruptcy cost, the greater the debt used in the company's capital structure, the greater the benefits of tax protection obtained on the company's net income, so that the company's value will continue to increase along with increasing debt. However, the existence of bankruptcy costs results, the higher the use of debt, the greater the threat of bankruptcy which will cause bankruptcy costs. To some extent the benefits arising from the interest tax protection as a result of the additional debt have been neutralized by the bankruptcy expense. The optimal capital structure occurs when the marginal tax protection benefit equals the costs associated with marginal bankruptcy.

Signaling theory, MM assumes that both investors and managers have the same information about the company's prospects (symmetric information), but in fact managers often have much better information than investors outside the company (asymetric information). The implication for capital structure decisions is that the issuance of shares is a negative signal for investors and therefore tends to depress share prices, even if the company's prospects are bright. Thus under normal conditions the company must use more equity and less debt than the trade-off model between tax benefits and bankruptcy costs suggests [2].

The implications of the pecking order theory of corporate funding are as follows: (1) companies prefer to use internal finance; (2) They adjust their target dividend payout ratio according to the investment opportunities, while trying to eliminate sudden dividend changes; (3) Low dividend policy, plus unpredictable fluctuations in investment profitability and opportunities. (4) If external funding is required, companies first issue the safest securities, namely starting with debt, then possibly mixed securities such as convertible bonds, and then equity as their last resort [3].

Brigham and Huston, suggest that in general, companies consider the following factors in making their capital structure decisions [2]. (1) Sales stability, companies whose sales are relatively stable are safer to use larger debt and are able to bear higher fixed costs of debt, than companies 
whose sales are unstable. (2) Asset structure, namely the ratio between current assets and fixed assets, also affects the use of external funds between debt and equity. (3) Operating leverage, assuming other things remains constant, companies that have low operating leverage have a better ability to use debt financing because of their low business risk.(4) The rate of growth, assuming other things remains constant, firms with faster growth are generally based on external financing. The use of debt or equity is considered based on flotation costs. (5) Profitability, usually companies with high profitability also have high investments, which are financed from the company's internal retained earnings, so the use of funds from debt is low.(6) Taxes, interest on debt are costs that reduce taxes, the higher the corporate tax rate, the higher the tax savings from debt. (7) Control, debt influence versus management control can affect the capital structure. If the current management has voting rights (more than $50 \%$ of the shareholders), but they are not in a position to buy additional new shares, then they will decide to choose debt as the new financing source. (8) Management Attitude, the managers of some companies are relatively conservative, using lesser debt financing than the average company in the industry, while others, who are more aggressive, use a higher proportion of debt financing. (9) Attitudes of lenders and rating agencies, regardless of managers' analysis of the company's leverage factor, the attitudes of lenders and rating agencies often influence their capital structure decisions. (10) Market conditions. changes in the stock and bond markets in the short and long term have an important impact on the optimal company's capital structure. (11) Internal conditions of the company. Internal conditions of the company can also affect the target capital structure.

The following are results of previous research relating to capital structure and its determinants.

Research on the determinants of the capital structure of Small and Medium Enterprises in the following countries: France, Greece, Italy, and Portugal using the panel data method, found that: firm size is positively related to leverage, asset structure has a negative relationship with leverage. So that companies that have a large proportion of intangible assets tend to use lower debt, profitability is negatively related to leverage, in line with the Packing Order theory which states that companies prefer to use funds that come from internal rather than external sources, risk is negatively related to leverage, the growth variable is not statistically significant with respect to leverage, for all samples taken in all the countries studied. The determinants of capital structure in the sample across countries are the same [20].

In a study entitled: The Impact of Firm and Industry Characteristics on Small Firms' Capital Structure, using a large and exclusive dataset panel to study the effect of company and industry characteristics on capital structure decisions in small and medium enterprises in the Netherlands. Consequently, the influence of firm characteristics is largely in line with the Pecking-Order Theory. The results of this study indicate that the fulfillment of capital needs starts from internal funds, then long-term debt in the next sequence is UKM equity. It is also known that the heterogeneity between industries is a determinant of the capital structure, in line with the pecking order capital structure theory and the trade-off structure. Their analysis of the effects between industries reveals that different industries exhibit different levels of leverage, in line with capital structure theory: packing orders and tradeoffs. The effect of firm characteristics for each industry is largely in line with Pecking order theory and this is found in almost all industries [13]. $\quad$ The study entitled: The Determinant of SME Capital Structure in Malaysia: Evidence from Enterprise 50 (E50) SME, analyzes the capital structure of SMEs in Malaysia that focuses on SME Enterprise 50 (E50). This study uses regression analysis of 334 companies, using accounting data for five years 2005 to 2009. Capital structure is the dependent variable referring to the company's debt ratio, which is divided into long-term debt ratios and short-term debt ratios. The independent variables are: age, size, reliability, liquidity, profit, growth, and taxes. This study found that company size has a significant effect on capital structure, tangible assets, liquidity and profitability are the main determinants of the capital structure of SMEs. Age and growth are significant, whereas tax is not an important consideration in capital structure decisions [18].

In a study entitled: Determinants of Firs Capital Structure an Empirical Analysis, examines the relative importance of factors: profitability, firm size, tangible assets, liquidity and asset turnover in capital structure decisions. A Romanian company listed on the Bucharest Stock Exchange operating in the construction industry sector. The data analysis method uses the ordinary last square regression method. It is found that the ratio of profitability and liquidity has a negative effect on the total debt ratio of Romanian companies, as well as tangible assets have a negative effect on leverage (ratio of total debt), while company size and turnover, total assets have a positive correlation with leverage The explanatory variable that has the highest effect on capital structure is profitability. Romanian company total debt ratio. Asset tangibility also has a negative impact on leverage, strengthening the findings of previous empirical studies which state that this indicator moves in the opposite direction to the debt ratio of companies in developing countries. On the other hand, company size and asset turnover have a positive correlation with leverage. The explanatory variable that has the highest influence on the choice of capital structure is profitability [22].

The study entitled: Are There Any Reliable Determining Factors for Capital Structure Decisions? The Empirical Study of SMEs in Various Portugal Regions, analyzed the relationship between the determinants of capital structure: profitability, firm size, age, asset structure and asset growth, found that the determinants of capital structure: size, age, intangible assets, and profitability, significantly explained the capital structure decisions in Portugal Small and Medium Enterprises (SMEs). The relationship of these variables with the capital structure is closer to the prediction of Pecking Order Theory than the 
prediction of Trade-off Theory. However, the two capital structure theories are not strong enough to explain the capital structure decisions of SMEs. There are differences in capital structure between regions, as well as the impact of: profitability, size, age, asset structure and growth on corporate debt [16].

Research entitled Determinant Influence on financial leverage in the Indian steel industry: A study of capital structure, with the aim of (1) identifying the significance of the determinants that affect capital structure, and (2) conducting extensive and empirical studies in an effort to estimate the correlation of capital structure determinants. There are seven determinants found, namely: profitability, asset structure, size, growth opportunities, tax protection of debt interest, liquidity, and risk. Research results: profitability has a very strong correlation with debt ratio, other determinants of capital structure, such as asset structure, size and tax protection of debt interest, statistically significant correlation with debt ratio, profitability and liquidity have a positive relationship with debt ratio [4].

The study, entitled The Effect of Profitability, Operating Leverage, Company Size and Sales Growth on Capital Structure, is aimed at obtaining empirical evidence of the effects of: profitability, operating leverage, company size and sales growth on the capital structure of banking companies listed on the Indonesia Stock Exchange for the period 2013-2015. Based on the results of multiple linear regression analysis, it was found that profitability and firm size had no effect on capital structure. However, operating leverage and sales growth have a negative and significant effect on capital structure [5].

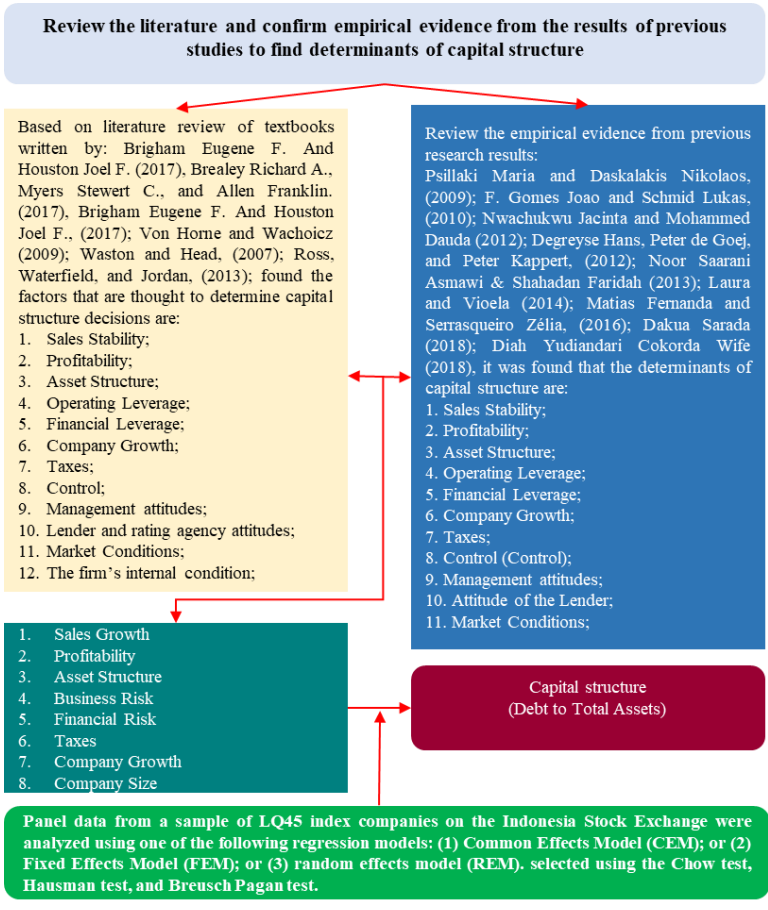

FiG.1.Research Framework

\section{B. Hypothesis}

Based on the literature review and the results of previous research, the researcher proposes the following hypothesis:

H1 :Sales growth, has a significant positive effect on the company's capital structure;

$\mathrm{H} 2$ :Profitability, has a significant negative effect on company structure;

H3 :Assets structure, has a negative effect on company structure;

$\mathrm{H} 4$ :Business risk, has a significant negative effect on the company's capital structure

H5 :Financial risk, has a significant negative effect on the company's capital structure

H6:Taxes, have a significant positive effect on the company's capital structure

$\mathrm{H} 7$ :Firms growth, has a significant positive effect on company structure

H8 :Firms size, has a significant positive effect on company structure.

\section{RESEARCH METHODS}

The population of this research is all companies that are included in the LQ45 Index on the Indonesia Stock Exchange from 2009 to 2018 . The sampling method in this study uses purposive random sampling, which is sample selection based on an assessment of several characteristics of the sample members adjusted to the research objectives [15 ]. The criteria for the companies selected as samples in this study are: (1) The company is consistently listed on the Indonesia Stock Exchange, and its shares have always been included in the LQ45 index from 2009 to 2018; (2) The company has complete financial data from 2009 to 2018 Based on these criteria, there are 20 companies that meet the sample criteria whith 180 panel data.

This research uses secondary data, which is sourced from the IDX book LQ45 February 2016 to February 2019 which is published regularly every February and August every year by the Indonesia Stock Exchange, downloaded from / /https://www.idx.co.id/data-pasar/laporanstatistik/ringkasan-performa-perusahaan-lq45/

In this study the data collected is panel data, namely a combination of coss sections and time series [10]. To answer the research questions and prove the hypothesis proposed, data analysis was carried out using the panel data regression method. The basic model of panel data regression [10]

$$
\begin{aligned}
& \text { Yit }=\beta_{1}+\beta_{2} X_{2} i t+\beta_{3} X_{3} i t+u i t \\
& \mathrm{i}=1,2,3, \ldots . \mathrm{n} \\
& \mathrm{t}=1,2,3, \ldots \mathrm{n}
\end{aligned}
$$

Where $\mathrm{i}$ shows the cross section of the units $\mathrm{i}$ and $\mathrm{t}$ shows the time period $t$. $i$ depends on the object under study, while $t$ depends on the time span of the observation. There are three panel data regression estimation techniques, namely (1) Common Effects Model (CEM); (2) Fixed Effects Model (FEM) or also known as least-squares dummy variable (LSDV) model; and (3) random effects model (REM) [10]. There are three tests used to determine 
the most appropriate technique for estimating panel data regression. First, the $\mathrm{F}$ test is used to select the ordinary least squares model (OLS) or the common effects model (CEM) or fixed effects model (FEM); second Langrange Multiplier test to choose between OLS and random effects models; Finally, to choose between a fixed effect or a random effect, the Hausman test is used [26].

\section{A. Dependent Variable}

The dependent variable in this study is the capital structure, namely the combination of financing between debt and equity [3]. Can be measured using a leverage ratio which shows the extent to which a company uses debt to fund its assets. In this study, the capital structure will be proxied by the ratio of total debt to total assets (debt to asset ratio, DAR) which is formulated as follows:

$$
\text { Debt to Asset Ratio }(\mathrm{DAR})=\frac{\text { Total Liabilities }}{\text { Total Assets }}
$$

\section{B. Independent Variable}

- $\quad$ Sales growth (S_GRT), calculated by the formula:

$$
\text { Sales Growth }=\frac{\operatorname{Sales}(\mathrm{t})-\operatorname{Sales}(\mathrm{t}-1)}{\operatorname{Sales}(\mathrm{t}-1)}
$$

Note: period $\mathrm{t}$, is the current period; Period $\mathrm{t}-1$ is the previous period.

- $\quad$ Profitability, This study uses return on total assets (ROA) as a measure of company profitability. According to the IDX LQ45 2017 book, ROA is calculated by the following formula.

$\mathrm{ROA}=\frac{\text { Profit for The Periode }}{\text { Total Assets }} \times 100 \%$

- Formulated as percentage of fixed assets on total assets and representing by FATA symbol.

$$
\text { Fixed asset to total Assets }=\frac{\text { Fixed Assets }}{\text { Total Assets }} \times 100 \%
$$

- Business risk is measured by degree of operating leverage (DOL). The percentage change in operating profit divided by the percentage change in output (or sales) that causes the change in profit [24].

$$
\text { DOL on Sales }(X)=\frac{\% \text { Change on EBIT }}{\% \text { Change on sales }}
$$

- Financial risk is measured by Degree of Financial Leverage (DFL), which is the percentage change in earnings per share, divided by the percentage change in operating profit (EBIT), which results in changes in earnings per share [24].

$$
\mathrm{DFL}_{\text {on EBIT } \mathrm{x}}=\frac{\% \text { Change on EPS }}{\% \text { Change on EBIT }}
$$

- Taxes, is the tax percentage of net profit before tax, calculated by the formula:

Identify applicable sponsor/s here. If no sponsors, delete this text box (sponsors).

$$
\text { Tax Rate }=\frac{\text { Tax }}{\text { Income Before Tax }} \times 100 \%
$$

- Firm growth, In this study, it is measured from the growth rate of the company's assets which is calculated by the following formula.

$$
\begin{aligned}
& \text { Assets Growth Rate } \\
& =\frac{\text { Total Assets }(t)-\text { Total assets }(t-1)}{\text { Total Assets }(t-1)}
\end{aligned}
$$

- Firm size is measured using the log natural of the company's total assets, which can be formulated as follows:

Firm Size $=$ Log natural of total assets (LnTA)

\section{RESEARCH RESULTS}

After testing panel data regression models to obtain the most suitable estimation model between CEM, FEM, and REM using the Chow test, Hausman test, and / or the Breusch-Pagan Lagrange Multiplier (BP LM) test, the most appropriate model is obtained. Fixed-Effect Model.

To find the best linear unbiased estimator (BLUE) regression model, the Fixed Effect Model with Generalized Least Square (FGLS) was used. The finel results are shown in the following table.

TABLE 1. RESEARCH RESULTS

\begin{tabular}{lrrrc}
\multicolumn{1}{c}{ Variable } & Coefficient & Std. Error & t-Statistic & Prob. \\
\hline C & 1.347278 & 0.125058 & 10.77322 & 0.0000 \\
S_GRW & 0.049962 & 0.020396 & 2.449618 & 0.0154 \\
ROA & -0.632472 & 0.064779 & -9.763466 & 0.0000 \\
FATA & -0.083729 & 0.040786 & -2.052877 & 0.0418 \\
DOL & 0.000989 & 0.000500 & 1.975834 & 0.0500 \\
DFL & 0.000669 & 0.000351 & 1.903371 & 0.0589 \\
TAX & 0.107402 & 0.077888 & 1.378932 & 0.1697 \\
LN_TA & -0.040455 & 0.006815 & -5.935973 & 0.0000 \\
A_GRW & 0.028143 & 0.026116 & 1.077627 & 0.2829 \\
\hline \hline
\end{tabular}

Cross-section fixed (dummy variables)

\begin{tabular}{cccc}
\hline \multicolumn{4}{c}{ Weighted Statistics } \\
\hline \hline R-squared & 0.991395 & Mean dependent var & 0.856617 \\
Adjusted R-squared & 0.989867 & S.D. dependent var & 0.700168 \\
S.E. of regression & 0.047888 & Sum squared resid & 0.348571 \\
F-statistic & 648.6199 & Durbin-Watson stat & 1.276502 \\
Prob(F-statistic) & 0.000000 & & \\
\hline
\end{tabular}

based on the research results in the table above, it can be stated as follows:

1. Sales growth variable (S_GRW) has a significant positive effect on capital structure (DAR). This means that a stable and high enough sales growth allows the company to use more debt in its capital structure. This finding is in accordance with the theory of financial management in general and in particular the theory of capital structure, as well as the findings from the research results that become the reference of this study [2] and [3].

2. Profitability variable (ROA), has a significant negative effect on the capital structure of the companies that are included in the LQ45 index on the Indonesia Stock Exchange, meaning that the higher the company's profitability, the lower the company's dependence on funding from debt so that the proportion of debt in the 
company's capital structure decreases. [2], [3], [4], [5], 16] [18], [20] and [22].

3. Asset structure variable (FATA), which is proxied by the proportion of fixed assets in the company's asset structure, has a significant negative effect on the capital structure, meaningthat the greater the proportion of fixed assets in the company's asset structure, thelower the funding proportion of debt used by the company. [2], [16], and [20].

4. Firm size variable, has a significant negative effect on capital structure. The results of this study are consistent with the results of previous studies [16], [18], [20], and [22], but the effect is negative. This is possible because the profitability is able to meet the funding needs of the company, so the decision on its capital structure tends to follow the packing order theory.

5. The adjusted R-squared resulting from the cross-section fixed (dummy variables) model is very high, namely 0.98 , which indicates that $98 \%$ of changes in capital structure can be explained by variables that significantly determine the company's capital structure. companies in the LQ45 index on the Indonesia Stock Exchange.

\section{CONCLUSION}

Factors that are supposed to determine the capital structure of companies included in the LQ45 index on the Indonesia Stock Exchange in this study that significantly determine capital structure decisions are: sales growth, profitability, asset structure, and company size. Profitability and firm size variables dominate the decisions on the capital structure of companies that are included in the LQ45 index on the Indonesia Stock Exchange, because these two variables have the strongest correlation with the capital structure. The decision on the company's capital structure that lasts for 10 years on the LQ45 index approaches the Packing Order Capital Structure Theory. This finding is in line with the packing order theory presented by Brealey, Myers, and Allen [3], as well as several research results that serve as the reference for this study.

\section{REFERENCES}

[1] Bambang Riyanto, Fundamentals of Corporate Finance, 4th edition, BPFE: Yogyakarta, 1998.

[2] Brigham Eugene F. And Houston Joel F., Fundamentals of Financial Management, 12th Edition, South-Western Cengage Learning: US., 2017.

[3] Brealey Richard A. , Myers Stewert C., and Allen Franklin, Principles Of Corporate Finance, 12th Edition, McGrawHill/Irwin: New York, 2017.

[4] Dakua Sarada, Effect of Determinants on Financial Leverage in Indian SteelIndustry: A study on capital structure, DOI: 10.1002/ijfe.1671, Weley, 2018:1-10.

[5] Diah Yudiandari Cokorda Istri, Influence Profitability, Operating Leverage, Company Size and Growth of Sales On Capital Structure, E-Journal of Accounting, University of Udayana Vol.22.1, p. 408437, ISSN: 2302-8556. January (2018): Doi:Https://Doi.Org/10.24843/Eja.2018.V22.I01.P16

[6] Ehrhardt Michael C. And Brigham Eugene F., Financial Management Theory and Practice, 15e, South-Western Cengage Learning: Australia, 2017.

[7] Fabozzi, Frank J., Capital Market, Financial Management, and Investment Management, John Wiley \&Sons., Hoboken, New Jersey,2009.
[8] F. Gomes Joao And Schmid Lukas, Levered Returns, The Journal Of Finance, VOL. LXV, NO. 2, APRIL 2010

[9] Ghozali, I, Aplikasi Analisis Multivariate dengan Program IBM SPSS 21 Update PLS Regresi. Semarang: Badan Penerbit Universitas Diponegoro, 2013.

[10] Gujarati, Damodar, Fundamtal Econometrics, Jakarta:Salemba Empat, 2012.

[11] Hartono, J., Portfolio Theory and Investment Analysis. Yogyakarta: BPFE-YOGYAKARTA, 2017.

[12] Harmono,Financial Management Based on the Balanced Scorecard (Theory, Case, and Business Research Approaches). Jakarta: Bumi Aksara, 2009.

[13] Hans Degryse, Peter de Goeij, Peter Kappert, The impact of firm and industry characteristics on small firms' capital structure, Small Bus Econ,38:431-447 DOI 10.1007/s11187-010-9281-8, 2012.

[14] Jumingan,Financial Statement Analysis. Jakarta: Bumi Aksara, 2006.

[15] Kasmiarno, et al,Analysis of the Influence of Economic Indicator and Islamic Banking Performance on Labor Absorption in Islamic Banking in Indonesia 2008-2014),Journal of Islamic Economics Theory and Applied Vol. 4 No. January 1, 2017: 14-26, 2017.

[16] Matias Fernanda and Serrasqueiro Zélia, Are there reliable determinant factors of capital structure decisions? Empirical study of SMEs in different regions of Portugal, Research in International Business and Finance, Published by Elsevier, 2016, http://dx.doi.org/doi:10.1016/j.ribaf.2016.09.014

[17] Megginson Wlliam L., Corporate Finance Theory, Addisionwesley Educational Publisher Inc.: Massachusetts,1997.

[18] Noor Saarani Asmawi \& Shahadan Faridah, The Determinant of Capital Structure of SMEs in Malaysia: Evidence from Enterprise 50 (E50) SMEs, Asian Social Science; Vol. 9, No. 6; 2013 ISSN 1911-2017 E-ISSN 1911-2025, Published by Canadian Center of Science and Education, 2013.

[19] Nwachukwu Jacinta and Mohammed Dauda, Business Risk, Industry Affiliation, and Corporate CapitalStructure: Evidence From Publicly Listed Nigerian Companies, Journal of African Business, 13(1), 5-15, Taylor \& Francis Group, LLC ISSN: 15228916, 2012.

[20] Psillaki Maria and Daskalakis Nikolaos, Are the determinants of capital structure country or firm specific?, Small Bus Econ (2009) 33:319-333, DOI 10.1007/s11187-008-9103-4, 2009.

[21] Ross Stephen A., Westerfi Randolph W., Jordan Bradford D., Fundamentas of Corporate Finance, tenth Editin, McGrawHill/Irwin: New York, 2013.

[22] Serghiescua Laura and Viorela-Ligia Videan, Determinant Factors Of The Capital Structure Of A Firm- An Empirical Analysis, Procedia Economics and Finance 15 ( 2014 ) 1447-1457; Published by Elsevier, 2014.

[23] Suad Husnan,Financial Management Theory and Application (Long-Term Decisions), Edisi Pertama, BPFE: Yogyakarta, 1985.

[24] Van Horne James C. And Wachowichz John M., Jr.,Fundamentals of Financial Management, 13th Edition, Prentice Hall- Pearson Education Limited: Harlow, 2009.

[25] Watson Denzil and Head Antony,Corporate Finance Principles \& Practice, Fourth edition, Pearson Education Limited: Harlow, 2007.

[26] Widarjono, Agus, Introductory Econometrics and Its Application Accompanied by the Eviews Guide, Fifth Edition, UPP STIM YKPN, 2018. 